УДК 94(477.8):355“1944”

DOI:

Микола Галів, доктор педагогічних наук, доиент кафедри історії України Дрогобицького державного педагогічного університету імені Івана Франка

Олександра Свйонтик, кандидат педагогічних наук, дочент кафедри загальної педагогіки та дошкільної освіти Дрогобицького державного педагогічного університету імені Івана Франка Мирослав Ющишин, здобувач другого (магістерського) рівня вищяої освіти Дрогобицького державного педагогічного університету імені Івана Франка

\title{
НАУКОВО-ПЕДАГОГІЧНІ КАДРИ ЛЬВІВСЬКОГО ДЕРЖАВНОГО ПЕДАГОГІЧНОГО ІНСТИТУТУ У ПЕРШІ ПОВОЄННІ РОКИ (1944-1953): ПОВСЯКДЕННЯ ПРОФЕСІЙНОЇ ДІЯЛЬНОСТІ
}

У статті висвітлено повсякденні аспекти професійної діяльності науково-педагогічних прачівників Львівського державного педагогічного інституту у перші післявоєнні роки (1944-1953). Встановлено, щэо впродовж окресленого періоду відбувалося становлення науково-педагогічного колективу інституту, зростання його кількісного та якісного складу. Чисельність викладачів за цей час зросла удвічі, збільшилася кількість працівників із науковими ступенями. Освітня діяльність викладачів підлягала суворій регламентачії, що проявлялося у чіткому дотриманні графіків навчального процесу, наданні групових та індивідуальних консультацій студентам, участі в численних засіданнях і нарадах. Під впливом ідеологічних кампаній в СРСР викладачі Львівського державного педагогічного інституту змушені були уводити до програм навчальних дисииплін прачі радянських політичних діячів. Навчальна діяльність викладачів суворо контролювалася не лише адміністрацією інституту, але й Міністерством освіти УРСР та Міністерством вищої освіти СРСР. Значну увагу керівництво та викладачі інституту приділяли науковій роботі, наголошуючи на потребі захисту дисертачій, публікації наукових прачь. Важливе значення мало започаткування збірника "Наукові записки Львівського державного педагогічного інституту” (1947). Велику частину професійного часу викладачів займала громадсько-політична робота та співпраия зі школами. У згаданий період в інституті працювали низка відомих учених: фізик Роман Цегельський, математик Володимир Левицький, історики Маврицій Горн і Василь Інкін, педагог Олександр Дзеверін, біолог Іван Носкевич, філолог Микола Бойчук.

Ключові слова: науково-педагогічні прачівники; Львівський державний педагогічний інститут; повсякденне життя; наукова робота; репресії.

Jim. 18.

Mykola Haliv, Doctor of Sciences (Pedagogy), Associate Professor of the History of Ukraine Department, Drohobych Ivan Franko State Pedagogical University

Oleksandra Sviontyk, Ph.D.(Pedagogy), Associate Professor of the General Pedagogy and Preschool Education Department, Drohobych Ivan Franko State Pedagogical University

Myroslav Yushchyshyn, Master's Student, Drohobych Ivan Franko State Pedagogical University

\section{SCIENTIFIC AND PEDAGOGICAL STAFF OF THE LVIV STATE PEDAGOGICAL INSTITUTE IN THE FIRST POST-WAR YEARS (1944 - 1953): EVERYDAY PROFESSIONALACTIVITY}

The article covers everyday aspects of professional activity of scientific and pedagogical workers of the Lviv State Pedagogical Institute in the first postwar years (1944-1953). It is established that during the outlined period there was a formation of scientific and pedagogical collective of institute, growth of its quantitative and qualitative structure. During this time, the number of teachers has doubled, the number of employees with degrees has increased. The teachersj educational activities were subject to strict regulation, which was manifested in strict adherence to the schedules of the educational process, providing group and individual consultations to students, participation in numerous meetings and conferences. Under the influence of ideological campaigns in the USSR, professors of the Lviv State Pedagogical Institute were forced to introduce the work of Soviet politicians into the curricula. The educational activity of professors was strictly controlled not only by the administration of the institute, but also by the Ministry of Education of the USSR and the Ministry of Higher Education of the USSR. The management and professors of the institute paid considerable attention to scientific work, emphasizing the need to defend dissertations and publish scientific papers. The launch of the collection "Scientific Notes of the Lviv State Pedagogical Institute"

(C) М. Галів, О. Свйонтик,

М. Ющишин, 2021 


\section{НАУКОВО-ПЕДАГОГІЧНІ КАДРИ ЛЬВІВСЬКОГО ДЕРЖАВНОГО ПЕДАГОГІЧНОГО ІНСТИТУТУ У ПЕРШІ ПОВОСННІ РОКИ (1944-1953): ПОВСЯКДЕННЯ ПРОФЕСІЙНӦ̈ ДІЯЛЬНОСТІ}

(1947) was important. The most of part of teachersj professional time was occupied by public and political work and cooperation with schools. During this period, the institute employed a number of famous scientists: physicist Roman Tsegelsky, mathematician Volodymyr Levitskyi, historians Maurice Horn and Vasyl Inkin, pedagogue Olexander Dzeverin, biologist Ivan Noskevich, philologist Mykola Boychuk.

Keywords: scientific and pedagogical workers; Lviv State Pedagogical Institute; everyday life, scientific work; repressions.

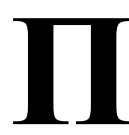

остановка проблеми. Важливим завданням дослідження історії будьякої освітньої інституції є вивчення складу і діяльності іï педагогічного колективу. Досліджуючи історію Львівського державного педагогічного інституту (далі ЛДПІ), важливо проаналізувати кількісні і якісні показники професорсько-викладацького складу вишу, зміст і форми повсякденної професійної діяльності викладачів в умовах сталінського тоталітаризму й уніфікованого та суворо регламентованого функціонування радянської вищої школи.

Аналіз останніх досліджень. Існування і окремі аспекти діяльності ЛДПІ висвітлено у монографіях Ю. Курносова і Р. Ростикаса [11], I. Кошарного [11], В. Майбороди [13], статті Т. Марусик та С. Герегової [14], дисертаційних дослідженнях Н. Головка, Т. Кобзарєвої, О. Сергійчука, С. Буряк, А. Булди, Н. Сірук. Слід відзначити й студії, присвячені науковопедагогічній інтелігенції західних областей України, зокрема праці О. Рубльова та Ю. Черченка [16], О. Лукјяненка [12], Р. Попп [15], О. Свйонтик [17] та ін. Однак синтезованого дослідження повсякденних аспектів діяльності науково-педагогічних кадрів ЛДПІ наразі немає.

Мета статті - дослідити повсякденні аспекти професійної діяльності науково-педагогічних працівників ЛДПІ у перші післявоєнні роки (19441953).

Виклад основного матеріалу. ЛДПІ було засновано 1940 р. У роки німецької окупації заклад не діяв. 3 жовтня 1944 р. ЛДПІ у складі мовнолітературного, історичного, фізико-математичного та природничого факультетів розпочав навчальний процес. Директором вишу став професор С. Смолінський $[6,29 ; 7,19] .31950$ р. цю посаду займав Г. Ломов $[9,44]$.

Упродовж 1944/45 н.р. в ЛДПІ сформувалися і діяли 13 кафедр: основ марксизму-ленінізму, педагогіки, української мови, української літератури, російської мови, російської літератури, польської мови та літератури, фізики, математики, природознавства, іноземних мов та військовофізичної підготовки. У складі кафедр працювали 71 викладач, 3 них 60 штатних, 11 сумісників. Власне сумісниками були переважно працівники Львівського державного університетуімені І.Я. Франка (далі - ЛДУ): професори Янов, Рудницький,
Волков, Попов, Міліянчук, старший викладач М. Шаповалова. За науковими ступенями, вченими званнями, посадами науково-педагогічні працівники ЛДПІ розподілялися так: докторів наук - 10, “місцевих докторів" (докторів філософії) 6 , кандидатів наук -9 , професорів -10 , доцентів - 14 , старших викладачів - 20, викладачів і асистентів - 27 [6, 2-2зв].

У першому семестрі 1944/45 н.р. в ЛДПІ відчувалися значні труднощі 3 науковопедагогічними кадрами, з огляду на що частина дисциплін не викладалася. Так, на історичному факультеті були вакансії на посади викладачів основ марксизму-ленінізму, історії народів СРСР, політекономії, діалектичного матеріалізму, історичного матеріалізму, української літератури, методики викладання історії. На мовнолітературному факультеті не було викладачів історії російської мови, історії української мови $з$ діалектологією, вступу до літературознавства, методики російської мови та літератури. На фізико-математичному факультеті була вакансія методиста навчання математики. У другому семестрі цього ж навчального року інститут здебільшого було укомплектовано науковопедагогічними кадрами шляхом запрошення на роботу частини професорів ЛДУ як сумісників $[6,3]$.

Наприкінці 1944/45 н.р проявилася ще одна проблема кадрового характеру: деякі викладачі не були достатньо підготовлені для роботи у вищій школі, а тому потребували заміни. До таких працівників дирекція ЛДПІ зарахувала: викладача історії народів СРСР Д. Солом'яного, викладача історії середніх віків П. Кривоносюка (кафедра історії), викладачку кафедри української мови О. Ковалик. Остання не могла “оволодіти аудиторією, організувати студентів на виконання самостійних завдань, школярські методи роботи". Для остаточного укомплектування ЛДПІ науковопедагогічними кадрами потрібно було ще наприкінці 1944/45 н.р. замістити такі вакантні посади: доцента діалектичного матеріалізму та історичного матеріалізму; доцента загальної літератури; двох викладачів фізкультури; завідувача кафедри російської мови (бо т.в.о. завідувача кафедри В. Бродська неодноразово порушувала питання про ii звільнення від завідування кафедрою) [6, 3-3зв].

3 метою підвищення професійного рівня 
науково-педагогічних працівників у 1944/45 н.р. під керівництвом кафедри педагогіки започатковано “педсемінар для викладачів", де розглядали такі питання: методика і техніка лекцій у педагогічних вишах, основні засади і критерії оцінок, методика і техніка колоквіумів, методика і техніка проведення екзаменів $[6,8]$. Одними 3 найкращих педагогів дирекція ЛДПІ вважала старших викладачів О. Федченка та Г. Ігнатова. При цьому визнавала "нерівність" педагогічної кваліфікації викладачів, зазначаючи, що “на високому науковому рівні й майстерно з боку викладу” викладає українську літературу доц. I. Романченко, але “досить елементарно” викладач М. Дуліба; якісно викладає російську літературу доц. Б. Сьомкін і “досить елементарно” - викладач О. Скляренко. Викладачі історії В. Горбатюк, Г. Гладківська, А. Коваленко, М. Думка “подають матеріал цікаво і на високому науковому рівні”, водночас викладач П. Кривоносюк “елементарно, по-школярському” [6, 23в-3]. Частина викладачів, а саме Б. Сьомкін, Ю. Редько, I. Романченко, П. Кривоносюк, надавали студентам книги з власних бібліотек $[6,14]$.

Засідання кафедр ЛДПІ відбувалися двічі на місяць. Щомісяця заслуховували звіти членів кафедри про наукову роботу. До найкращих у 1944/ 45 н.р. зарахували кафедри: фізики, української мови, природознавства, педагогіки. Було відзначено кафедру фізики (завідувач кафедри доц. Р. Цегельський), високо оцінено іїі методичну, організаційну і наукову роботу. Кафедра української мови (завідувач - М. Бойчук), багато уваги приділяла роботі власного кабінету та добре організувала методичну роботу. Кафедра історії (завідувач - А. Коваленко) систематично допомагала студентам в організації їхньої самостійної роботи та зуміла зацікавити студентів роботою студентського гуртка, одного із найкращих в інституті. Кафедра природознавства розгорнула широку науково-дослідницьку роботу. Високі показники наукової роботи у той час виявили такі працівники ЛДПІ: І. Романченко, Б. Сьомкін, В. Горбатюк, А. Коваленко, М. Бойчук, Ю. Редько, Р.Цегельський, М. Мельник, М. Янушевич, П. Федченко [6, 8зв-9].

Проте 313 кафедр інституту у 1944/45 н.p. науково-дослідницькою роботою займалося 11 , не провадили наукових досліджень кафедри основ марксизму-ленінізму та військової підготовки. За пропозицією Наркомату освіти УРСР, тематика науково-дослідницької роботи ЛДПІ була скерована на розв'язання “актуальних проблем радянської школи”, тому значна частина праць викладачів були науково-педагогічними та методичними. Деякі наукові студії мали “перехідний характер" - це переважно дисертаційні праці, розпочаті ще до 1941 р. Так, завідувач кафедри педагогіки В. Зиза продовжував працювати над дисертацією “Школа при Петрі I”, яку було виконано ще до війни, але іiї частина загинула під час німецької окупації. Директор педагогічного інституту, професор кафедри педагогіки С. Смолінський опублікував три педагогічні статті у газеті "Вільна Україна" та підготував монографію “Методика виховання і зміцнення свідомої дисципліни в радянській школі” (10 друк. арк., апробовано в Українському НДІП), яку заплановано видати в 1946 р., а також статтю "Боротьба з залишками впливів реакційних педтечій в школах західних областей України" (подано до друку у журнал "Радянська школа") [6, 14зв-15]. На кафедрі української літератури кандидат філологічних наук доц. І. Романченко працював над докторською дисертацією “Драгоманов-літературознавець”. Крім того, він підготував до друку працю “Франко і російська революційно-демократична література“, а також опублікував чотири статті в газетах "Вільна Україна" і “Радянська Україна". На кафедрі історії науковою роботою активно займався лише проф. М. Думка, який закінчив опрацювання матеріалу на тему “Слов'янсько-германські взаємини на протязі стародавньої історії’ [6, 15зв-16]. На 1945 р. в інституті було заплановано і виконувалося 28 наукових тем (одну тему виконували 1 або 2 викладачі, інколи - вся кафедра) [6, 27-28].

11-13 липня 1945 р. у ЛДПІ відбулася наукова сесія. На пленарному засіданні виступили заступник директора інституту з наукової роботи В. Зиза, директор проф. С. Смолінський (доповідь “Ленінська теорія відображення як основа радянської педагогіки та психології), доц. I. Романченко (“Франко і російська демократична література"), доц. Б. Сьомкін (“Міжнародне значення російської літератури”). Відтак роботу ceciï планувалося проводити у секціях: a) педагогічній (доповіді завідувача кафедри педагогіки В. Зизи, ст. викладача І. Гриневицького, професора М. Думки); б) мови і літератури (доповіді ст. викладача I. Ковалик, завідувача кафедри української літератури доцента П. Яременка, завідувача кафедри української мови М. Бойчука, декана мовно-літературного факультету Ю. Редька, проф. І. Янова); в) фізико-матемтаичних i природничих наук (доповіді проф. І. Носкевича, доцентів М. Мельника, Богачевського, доцент Р. Цегельського, ст. викладача С. Білінкевича) [6, 29-29зв].

Станом на 1 серпня 1945 р. у штаті ЛДПІ 


\section{НАУКОВО-ПЕДАГОГІЧНІ КАДРИЛЬВІВСЬКОГО ДЕРЖАВНОГО ПЕДАГОГІЧНОГО ІНСТИТУТУ У ПЕРШІ ПОВОЄННІ РОКИ (1944-1953): ПОВСЯКДЕННЯ ПРОФЕСІЙНОӤ ДІЯЛЬНОСТІ}

налічувалося лише 55 викладачів. 3 них науковий ступінь мали директор С. Смолінський кандидат педагогічних наук, викладач кафедри психології В. Метельський - “місцевий доктор”, доценти кафедри історії В. Горбатюк та Г. Глядківська - кандидати історичних наук, професор І. Янов - доктор філософії, доцент кафедри української мови I. Грицютенко кандидат філологічних наук, завідувач кафедри української літератури П. Яременко та доцент цієї ж кафедри I. Романченко - кандидати філологічних наук, завідувач кафедри фізики Р. Цегельський - “місцевий доктор”, завідувач кафедри математики Ю. Богачевський та професор-сумісник цієї ж кафедри В. Левицький - “місцеві доктори”, професор кафедри природознавства I. Носкевич - “місцевий доктор", завідувач цієї ж кафедри Г. Ткаченко кандидат природничих наук. За національністю більшість викладачів складали: українці - 48, росіян - 3 (Г. Ігнатов, Л. Попова, Б. Сьомкін), поляків - 3 (І. Янов, 3. Кірхнер, А. Лапчинська), євреїв - 1 (В. Бродська) [6, 20-22].

На 1946/47 н.р. у ЛДПІ діяли 15 кафедр: марксизму-ленінізму, педагогіки, історії СРСР, загальної історії, української мови, української літератури, російської мови, російської літератури, математики, фізики, ботаніки, зоології, хімії, іноземних мов, і військова кафедра (після їі ліквідації - кафедра фізкультури). На чотири факультети в педагогічному інституті було три декана: факультету мови і літератури; факультету iсторії і фізико-математичного факультету. Відзначимо, що методичною і науковою роботою деканат не займався. Він в основному виконував диспетчерські обов'язки, складаючи розклади і контролюючи їх виконання. Деканат розглядав справи окремих студентів, робив їм зауваження, приймав заходи впливу (переконання чи примус). Але значної виховної роботи деканати не проводили. Цією роботою переважно займалася “навчальна частина інституту”. Керівництво навчальним процесом полягало в установчих та інститутських методичних нарадах, які відбувалися кожного місяця. На цих нарадах розглядали такі питання як організація самостійної роботи студентів, методика проведення екзаменів і заліків, методи організації навчального процесу у вишах. Рада інституту за 1946 - 1947 н.р. провела 15 засідань. 330 питань 14 питань мали навчальний і науково-методичний характер: про ідеологічну роботу у вузі, планування наукової роботи і методах її виконання, виховання вчителя у педвузі, організації педагогічної практики, про методику і техніку проведення екзаменів і заліків, організації звітної наукової конференції, про рішення ЦК КП(б)У з викладання суспільнозначимих предметів у львівських вузах, критики націоналістичних “збочень” в історії та літературі України, реалізації постанов ЦК ВКП(б) про журнали “Зірка” і “Ленінград”. Останні питання розглядалися протягом усього навчального року, згідно з планом проведення рішень ЦК ВКП(б) [7, 83в-9].

Підвищення т.зв. “ідейно-теоретичного рівня" викладачів ЛДПІ відбувалося шляхом спеціально організованого наукового семінару, консультацій для тих працівників, які самостійно працювали над “першоджерелами марксизму-ленінізму”. На теоретичних конференціях, які двічі відбулися у 1946 / 47 н.р., основними темами були: національне питання, вивчення біографії Леніна і Сталіна. Викладачі “з місцевого населення” приймали активну участь у цих конференціях [7, 2]. Крім того, на кожну кафедру покладався обов'язок проводити роботу щодо підвищення “ідейнотеоретичного рівня і ділової кваліфікації членів кафедри". У зазначеному навчальному році недостатню активність у цьому напрямі показали кафедра російської літератури та кафедра зоології. Натомість кафедри педагогіки, української літератури, ботаніки, фізики, української мови, російської мови найбільш широко розгорнули таку роботу [7, 9-9зв].

370 викладачів ЛДПІ науковою роботою у 1946 / 47 н.р. займалися 40 осіб, причому 25 із них працювали над дисертаціями. На початку зазначеного академічного року укладено плани і тематики науково-дослідницьких робіт ЛДПІ на 1947 р. і на п’ятирічку. Так, на 1947 р. заплановано 43 роботи, які за формально-змістовими ознаками розподілялися так: монографії-9 тем; методичні посібники - 10 тем, експериментальні праці - 16 тем. Інші кафедри працювали над комплексними темами: кафедра української літератури (5 осіб) вивчала літературну спадщину I. Франка; п’ять членів кафедри російської літератури працювали на проблемою російською літератури в Західній Україні; чотири викладачі кафедри математики працювали над комплексною проблемою "Методика викладання шкільного курсу математики”; три викладачі кафедри зоології досліджували патогенні тварини Західної України. Через недостатність в ЛДПІ матеріальної бази для наукової роботи, деякі експериментальні дослідження викладачі проводили в інших закладах [7, 16-16зв]. У лютому 1947 р. в інституті проведено третю наукову конференцію, на якій заслухано 30 доповідей. 338 наукових тем в 1946 р. закінчено 7, інші - продовжувалися і в 


\section{НАУКОВО-ПЕДАГОГІЧНІ КАДРИЛЬВІВСЬКОГО ДЕРЖАВНОГО ПЕДАГОГІЧНОГО ІНСТИТУТУ У ПЕРШІПОВОЄННІ РОКИ (1944-1953): ПОВСЯКДЕННЯ ПРОФЕСІЙНОӤ ДІЯЛЬНОСТІ}

1947 р. Дирекція ЛДПІ надавала викладачам відрядження до Москви, Ленінграда, Києва (на 18 відряджень витрачено 15230 крб.) [7, 16зв-17]. Важливо, що у 1947 р. побачили світ два випуски першого тому “Наукових записок” ЛДПІ, а до річниці “Жовтневої революції” підготовлено другий том збірника $[7,18]$.

Упродовж навчального року дисертацію на здобуття ступеня кандидата філологічних наук захистила К. Забарило. Чотири кандидати наук протягом навчального року стали доцентами. Три викладачі працювали над докторськими дисертаціями [7, 2-3]. Аспірантури в інституті не було, тож викладачі могли розраховувати лише на аспірантуру ЛДУ, проте там не велася підготовка 3 педагогічних і психологічних спеціальностей [7, 16]. У скерованому до Міністерства освіти УРСР звіті про роботу ЛДПІ (липень 1947 р.) директор С. Смолінський пропонував надати інститутові право приймати кандидатські екзамени i проводити захисти кандидатських дисертацій 3 педагогіки, психології, методики, оскільки “в західних областях України немає установ, які б мали аспірантуру з педагогічних наук” [7, 183в-19].

Науково-педагогічні працівники ЛДПІ намагалися дотримуватися трудової дисципліни. Однак траплялися і порушення. Наприклад, викладач Н. Коломойцев декілька разів не 3'явився на заняття, не попередивши адміністрацію закладу про поганий стан здоров'я чи інші причини [7, 13]. Викладачі кафедр були зобовјЖязані розробляти плани, тематику, календарний графік практичних і семінарських занять, стежити за самостійною роботою студентів, проводити за графіком консультації, займатися зі студентськими гуртками (останніх у 1947 р. налічувалося 11), вести масштабну “політико-виховну роботу” зі студентами [7, 9зв, 113в-13]. Особлива увага надавалася громадській роботі. Так, викладачі кафедри педагогіки у 1946/ 47 н.р. прочитали для вчителів, батьків учнів, мешканців Львова й області 58 лекцій і доповідей на теми комуністичного виховання дітей, методики навчання та виховання у школі $[7,13]$.

3 метою підняття якості викладання та виконуючи рішення оргбюро ЦК КП(б)У (лютий 1947 р.) про викладання суспільних наук у вищих навчальних закладах Львівської області, в ЛДПІ було проведено дві “виробничі наради”, на яких критикувалися недоліки і було накреслено заходи щодо їх усунення. Посилився контроль за якістю викладання шляхом взаємовідвідування лекцій і практичних занять 3 подальшим їх обговоренням. Заняття відвідували групи з 2-3-х викладачів, декани, завідувачі кафедр, а також директор інституту та його заступники. Так, директор С. Смолінський у 1946/47 н.р. відвідав 38 лекцій, заступник директора $з$ навчально-наукової роботи Г. Ткаченко - 46. Проводилося стенографування лекцій викладачів. Наприклад, застенографовано 1-3 лекції кожного викладача кафедри марксизмуленінізму, одну лекцію кожного викладача кафедри педагогіки і лекції окремих викладачів інших кафедр. Деякі стенограми надавалися для рецензування до інших вишів Львова. Крім того, на кафедрах розглядалися питання методики проведення практичних занять, консультацій i колоквіумів, педагогічної практики, застосування наочності, структуру лекцій тощо. Для викладачів і студентів було прочитано окрему доповідь щодо критики чинних програм 3 українського мовознавства, а на кафедрі української мови обговорено питання про “методику викладання української мови на курсах, де переважають студенти, які раніше не вивчали української мови" $[7,15-153$ в $]$.

Згідно з наказом директора ЛДПІ С. Смолінського, від 1 квітня 1946 р. встановлювалася заробітна плата науково-педагогічних працівників вишу у розмірі від 525 до понад 4 тис. крб. (за винятком директора, який отримував 6000 крб.). Так, завідувач кафедри марксизму-ленінізму О. Савчук, не маючи наукового ступеня, отримував заробітну плату у розмірі 4500 крб., решта три викладачі на цій же кафедрі отримували від 1050 до 1500 крб. На кафедрі педагогіки також працювали 4 викладачі, 3 них тільки завідувач О. Дзверін мав ступінь кандидата наук і місячний оклад - 3840 крб. Найменша заробітна плата була в О. Демкової 525 крб. На кафедрі історії працювали 8 викладачів, з яких двоє мали звання кандидата наук - Г. Глядківська та В. Горбатюк. Завідувач кафедри А. Коваленко не мав наукового ступеня, його зарплатня складала 1980 крб., решта викладачів отримували від 525 до 1600 крб., лише Г. Глядківська - 3200 крб. На кафедрі української літератури працювали 9 викладачів, з яких один мав звання кандидата наук. Місячний оклад завідувача М. Бойчука складав 1980 крб., заробітні плати викладачів - від 600 до 1200 крб. На кафедрі російської мови працювали 8 викладачів. Заробітна плата завідувача Я. Старухіна складала 3240 крб., а інших працівників кафедри - від 525 до 1600 крб. На кафедрі фізики, де працювали 4 викладачі, зарплата завідувача Р. Цегельського складала 3240 крб., у решти - від 1050 до 1500 крб. На кафедрі математики завідувач кафедри Ю. Богачевський отримував 1440 крб. на місяць, доцент В. Левицький - 1600 крб., а доцент 


\section{НАУКОВО-ПЕДАГОГІЧНІ КАДРИЛЬВІВСЬКОГО ДЕРЖАВНОГО ПЕДАГОГІЧНОГО ІНСТИТУТУ У ПЕРШІ ПОВОЄННІ РОКИ (1944-1953): ПОВСЯКДЕННЯ ПРОФЕСІЙНОӤ ДІЯЛЬНОСТІ}

П. Гржибовський -2300 крб. На кафедрі природознавства із 7 викладачів було 2 кандидати наук. Завідувач кафедри кандидат природничих наук Г. Ткаченко мав місячний оклад у розмірі 3840 крб., всі інші працівники - від 1150 до 1650 крб. На кафедрі іноземних мов працювали 3 викладачі, із них ніхто не мав наукового ступеня. Завідувач кафедри В. Пачковський отримував зарплатню у розмірі 1440 крб., викладач А. Лапчинська - 1050 крб., старший викладач М. Пушкар - 1500 крб. Завідувач кафедри військової підготовки полковник М. Журавель отримував 2500 крб. щомісяця [1, 1-4].

На початок 1948/49 н.р. викладацький склад ЛДПІ був повністю сформований, проте в дирекції виникали питання до його якості. В інституті був лише один професор, 20 доцентів, 22 старших викладачів, 44 асистентів і викладачів. Лише 21 викладач мав ступінь кандидата наук. Більшість викладачів українці - 62 особи, із них 11 були місцевими. Цікаво, що 36 осіб були членами і кандидати в члени ВКП(б). Більшість викладачів мали стаж педагогічної роботи у вишах від 5 до 10 років. У 1948 р. викладацький колектив збільшився на 9 осіб. За навчальний рік два викладачі інституту отримали ступінь кандидата наук [8, 2-2зв].

Міністерство освіти УРСР своїм наказом затвердило план науково-дослідницької роботи ЛДПІ на 1948 р. Однак у ньому відбулися зміни, оскільки на початку 1948/49 н.р. звільнилися викладачі А. Ігнатов, В. Зиза, М. Бурштейн, П. Сміян, М. Кривоносюк, І. Грицютенко, Г. Ткаченко, Х. Приступа. Їх теми вилучено 3 плану. Особистий науковий план не виконали доцент О. Дзеверін, викладач Л. Олександрова, доцент I. Балака, викладач Н. Скидан, асистенти Л. Романова, Т. Сахарова, ст. викладач В. Пачовський. Зате ст. викладач Й. Ейснер виконав понад план дві праці з фізики, які були надруковані в журналі “Фізика в середній школі”. 31 робота викладачів була виконана своєчасно, а 9 надруковані у “Наукових записках ЛДПІ” (том II). Серед них, крім праць знаних учених С. Смолінського, П. Яременка, була опублікована й стаття історика М. Горна (згодом працював у Польщі): "Розшарування селян Руського воєводства в середині XVII ст.” $[8,10]$. Доцент I. Романченко підготував докторську дисертацію “Драгоманов і Галичина", шість викладачів склали кандидатські іспити, завершили написання кандидатських дисертацій викладачі І. Донець, І. Довгаль, Я. Білоштан, Ю. Редько, А. Федченко [8, 103в].

За підсумками наукової роботи у 1949 рр. виявилися низка недоліків: викладач кафедри марксизму ленінізму М. Шумович не виконав своїх зобов'язань щодо наукової роботи за 1948 і 1949 рр.; доцент цієї ж кафедри О. Савчук не склав звіту про свою працю; ст. викладач кафедри російської і зарубіжної літератури Б. Сьомкін щорічно не виконував плани наукової роботи; слабкістю відзначалася наукова праця на кафедрах української мови і російської мови; кафедра фізичного виховання “не включилася” у наукову роботу вишу; низка опублікованих в “Наукових записках ЛДПI” статей була “дуже низької якості” [3]. Останній недолік навіть потрапив на шпальти республіканської преси [18]. Відзначимо, що наказом директора ЛДПІ від 28.04.1950 р. № 40 викладачів М. Шумовича та Б. Сьомкіна за невиконання плану наукової роботи передбачалося “навантажити навчальною роботою до існуючого максимуму” [3].

Основним засобом підняття “ідейнотеоретичного рівня" викладачів на той час був “марксистсько-ленінський семінар", який діяв під керівництвом завідувача кафедри марксизмуленінізму О. Савчука. Центральна тема семінару - "Партійність і наука". Представники кожної кафедри змушені були виступати з доповідями на цю тему, екстраполюючи ії на свою наукову галузь. 16 викладачів навчалися і закінчили Вечірній університет марксизму-ленінізму при Львівському міському комітеті КП(б)У. Парторганізація інституту впродовж 1948/49 н.р. провела дві перевірки вивчення викладачами “марксистськоленінської теорії” [8, 23в]. Продовжувалися перевірки занять викладачів. Зокрема, заступник директора I. Донець у зазначеному навчальному році відвідав 62 заняття, прочитав 38 стенограм лекцій. Акцентувалося питання щодо дотримання графіків семінарських занять, проведення групових та індивідуальних консультацій. Керівники курсових робіт не могли відтягувати рецензування на кінець року [8,53в-6]. Перевірка занять виявляла недоліки в роботі викладачів. Так, під час відкритої лекції П. Устінов завершив виклад матеріалу за 20 хвилин до кінця заняття. Виявлено "недостатню партійну загостреність" лекцій з українського фольклору, які проводив доц. П. Яременко [8, 4]. Наказом директора ЛДПІ від 08.06.1949 р. № 71 викладачам заборонялося порушувати графіки заліків і екзаменів, самовільно їх переносити [2, 71-72].

В умовах “ждановщини” дирекція ЛДПІ звітувала перед Міністерством освіти УРСР про відсутність у закладі випадків “злісного низькопоклонства перед буржуазною наукою культурою, а також космополітизму" [8, 23в]. 


\section{НАУКОВО-ПЕДАГОГІЧНІ КАДРИЛЬВІВСЬКОГО ДЕРЖАВНОГО ПЕДАГОГІЧНОГО ІНСТИТУТУ}

У ПЕРШІ ПОВОЄННІ РОКИ (1944-1953): ПОВСЯКДЕННЯ ПРОФЕСІЙНОЇ ДІЯЛЬНОСТІ

Водночас наголошувала на тому, що “пріоритет російської і радянської науки” найбільш повно відображався під час викладання не лише таких дисциплін, як історія і література, але і фізики, математики, хімії. На двох засіданнях Вченої ради ЛДПІ обговорювалася стаття А. Алентьєва “Проти низькопоклонства перед прогнилою культурою Заходу” (журнал “Більшовик”), відтак усі кафедри на своїх засіданнях розглянули питання про пріоритет “вітчизняної науки” у викладанні спеціальних дисциплін. Продовжував роботу політсемінар для викладачів інституту, який проводився кафедрою марксизму-ленінізму $[8,7-73 в]$.

Під впливом ідеологічної популяризації праць академіка Т. Лисенка, викладачі кафедри ботаніки і кафедри зоології взялися за перебудову змісту своїх дисциплін. 26 серпня 1948 р. було проведено спільне засідання біологічних кафедр інституту, на якому кандидат біологічних наук С. Рабінович виголосила доповідь про перебудову викладання курсу дарвінізму. Проте в її виступі, котрий стенографувався, були виявлені “вейсманістські тенденції і вейсманістсько-морганістські погляди”. Тож викладачку звільнили з інституту. Цікаво, що ії призначили лише в травні 1948 р., тому С. Рабінович не встигла прочитати жодної дисципліни [8, 12зв-13].

Штати викладацького складу ЛДПІ на 1950/ 51 н.р. були укомплектовані повністю, однак забезпечення інституту висококваліфікованими науковими кадрами продовжувало бажати кращого. У виші на той час працювали лише 22 викладачі зі званням доцента чи ступенем кандидата наук. ЛДПІ залишався єдиним закладом вищої освіти на Львівщині, у якому не було жодного доктора наук чи професора. П'ять iз 12 завідувачів кафедр не мали наукових ступенів. Хоча склад викладачів з науковими ступенями порівняно з минулим роком кількісно збільшився, але зростання було незначним і не вплинуло на поліпшення складу наукових кадрів в інституті. На пјяти кафедрах не було жодного працівника 3 науковим ступенем чи вченим званням. Особливо критична ситуація була на кафедрі української мови і кафедрі російської літератури, які “визначали обличчя філологічного факультету”: там працював один кандидат наук [9, 4-4зв].

20 грудня 1950 р. Колегія Міністерства освіти УРСР прийняла рішення про зміцнення ЛДПІ науковими кадрами. Дирекція ж інституту мало зробила для подальшого наукового зростання тих викладачів, які мали ступені кандидата наук. В ЛДПІ на той час були доценти, які захистили кандидатські роботи 10 - 12 років тому, однак нічого не зробили для написання докторських дисертацій. Деякі дисертаційні роботи виявилися безперспективними. Зокрема, доц. О. Дзеверін чотири роки працював над темою “Історія педагогічної думки на Україні”, а 1951 р. змушений був ії змінити [9, 5-6].

Серед викладачів 12 осіб були місцевими. Із цієї кількості наукові ступені мали двоє, здали кандидатські екзамени і працювали над дисертаціями - троє, здавали кандидатський іспит - семеро. У другому півріччі 1950/51 н.р. ЛДПІ поповнився кваліфікованими кадрами викладацького складу. Так, березні 1951 р. був оголошений конкурс, у результаті якого на науковопедагогічні посади обрали п'ять осіб, усі вони кандидати наук, у тому числі два представники місцевої інтелігенції $[9,7]$.

Аспірантури на 1951 р. в інституті все ще не було. За 1950 р. підготовлено до друку два томи “Наукових записок ЛДПІ”. Найбільш цінними працями викладачів інституту на той час були: монографія І. Півторадні “Архип Телесенко”, посібники С. Федчишин (співавтор) "Хрестоматія 3 літератури для польських шкіл”, І. Тесленка "Про геометричні задачі з додатком тригонометрії у 10 класі”. Значнуувагу викладачі приділяли питанням методики навчання учнів в школі [9, 40-41].

На педагогічну діяльність науковців ЛДПІ продовжували впливати ідеологічні віяння. Викладачі гуманітарних дисциплін змушені були уводити до змісту своїх лекцій тези 3 “мовознавчих праць” Й. Сталіна. Члени природничих кафедр, а також кафедри педагогіки і психології зосереджували увагу на спадщині I. Павлова [9, 19-22]. При цьому зміст програм і лекцій часто перевірялися не лише інститутською адміністрацією, але і комісіями Міністерства освіти УРСР, Управління вищої школи при Раді Міністрів УРСР, Міністерства вищої освіти СРСР $[9,13]$. Як наслідок, у роботі викладачів виявляли різноманітні недоліки, зокрема, працівників мовних кафедр розкритикували за “повільність у перебудові своєї праці”. Викладачку кафедри російської мови К. Голубіну звільнили з роботи, бо вона "не проявила достатнього бажання i енергії в справі ліквідації маррівських збочень у викладанні мови і впровадження у викладання геніальних сталінських положень про мову”. 3 інституту звільнили й старшу викладачку кафедри української мови 3. Самойленко, яка начебто методично неправильно будувала свої лекції, зокрема відволікалася й подавала студентам матеріал, що не стосувався теми лекції. Викладачеві логіки С. Федчишину зробили 
“серйозне попередження" за оперування під час викладу матеріалу “декількома вульгарними прикладами’. Цього ж викладача розкритикували за “неприпустимість самовільного відхилення від робочих планів”, який він порушив, працюючи на III курсі історичного факультету [9, 11-12].

Звісно, траплялися й помилки, пов'язані 3 невисокою кваліфікацією викладачів. Зокрема, старшого викладача кафедри російської літератури П. Устінова у 1951 р. розкритикували за використання при викладанні давньої російської літератури невдалих і “вульгаризаторських" прикладів і “політично шкідливі спроби прив’язати викладовий матеріал 3 сучасністю”: плач Ярославни повјязувався 3 плачем жінок у сучасних капіталістичних країнах, а образ землероба зі “Слова о полку Ігоря” співвідносився 3 образом колгоспника $[9,12]$. Незадоволення роботою викладачів кафедри російської літератури призвело до того, що на посаду завідувача цього структурного підрозділу запросили доцента ЛДУ В. Малкіна [9, 12-13].

Лекції викладачів мовних кафедр відвідувалися по 9-11 разів, крім того, було застенографовано 6 лекцій, котрі пізніше ретельно обговорювалися [9, 20]. У листопаді 1950 р. проведено для усіх викладачів ЛДПІ теоретичну конференцію, на якій підбиті “перші підсумки оволодіння викладацьким складом інституту геніальними працями товариша Сталіна 3 мовознавства" $[9,20]$. А в річницю з часу публікації мовознавчої праці радянського вождя в ЛДПІ проведена “ювілейна” науково-теоретична конференція викладацького складу вишу [9, 20-21]. Відзначимо, що у 1952/ 53 р. викладачі інституту змушені були студіювати ще одну працю Й. Сталіна - “Економічні проблеми соціалізму в СРСР” та рішення XIX з'їзду КПРС [5].

Важливим напрямом професійної діяльності науково-педагогічних працівників ЛДПІ залишалася співпраця зі школою. Кафедри впродовж 1950/ 51 н.р. проводили методичні конференції для вчителів Львова, виїзні засідання у школах, на які запрошували вчителів. 18 викладачів інституту брали участь в учительських конференціях, систематично відвідували уроки в середніх школах [9, 22-23]. Певною інновацією у співпраці зі школою стало проведення під час зимових канікул т.зв. “науково-педагогічної експедиції”. Вона полягала у тому, що за узгодженим із Львівськими обкомом КП(б)У та облвиконкомом планом 74 викладачі ЛДПІ виїхали на 5 днів (24-28.01.1951 р.) у школи сільських районів Львівщини 3 метою вивчити досвід вчителів, провести методичні конференції, ознайомитися 3 працею випускників інституту. Завдання було виконано, зокрема викладачі відвідали 503 уроки [3, 199-201; 9, 23]. Крім того, працівники ЛДПІ скеровувалися й до інших вишів. Так, ст. викладача кафедри марксизму-ленінізму П. Матюшенка з 31 жовтня до 5 листопада 1951 р. відрядили до Дрогобицького учительського інституту для “допомоги в організації навчальнометодичної роботи кафедр марксизму ленінізму та історії" $[4,44]$.

Висновки. Отже, впродовж окресленого періоду відбувалося становлення науковопедагогічного колективу ЛДПІ, зростання його кількісного та якісного складу. Чисельність викладачів за цей час зросла удвічі, збільшилася кількість працівників із науковими ступенями. Освітня діяльність викладачів підлягала суворій регламентації, що проявлялося у чіткому дотриманні графіків навчального процесу, наданні групових та індивідуальних консультацій студентам, участі в численних засіданнях і нарадах. Під впливом ідеологічних кампаній в СРСР викладачі ЛДПІ змушені були уводити до програм навчальних дисциплін праці радянських політичних діячів. Навчальна діяльність викладачів суворо контролювалася не лише адміністрацією інституту, але й Міністерством освіти УРСР та Міністерством вищої освіти СРСР. Значну увагу керівництво та викладачі ЛДПІ приділяли науковій роботі, наголошуючи на потребі захисту дисертацій, публікації наукових праць. Важливе значення мало започаткування збірника “Наукові записки ЛДПІ” (1947). Левову частину професійного часу викладачів займала громадсько-політична робота та співпраця зі школами.

\section{ЛІТЕРАТУРА}

1. Архів Дрогобицького державного педагогічного університету імені Івана Франка (далі-Архів ДДПУ). Ф. 1: ЛДПІ. Спр.: Книга наказів за 1945-1946 н.р.

2. Архів ДДПУ. Ф. 1: ЛДПІ. Спр.: Книга наказів 19481949 н.р.

3. Архів ДДПУ. Ф. 1: ЛДПІ. Спр.: Книга наказів 19501951 н.p.

4. Архів ДДПУ. Ф. 1: ЛДПІ. Спр.: Книга наказів за 1951/52 H.p.

5. Архів ДДПУ. Ф. 1: ЛДПІ. Спр.: Книга наказів за 1952/53 н.p.

6. Державний архів Львівської області (далі - ДАЛО). Ф. Р-7: Львівський державний педагогічний іститут. Оп. 1. Спр. 31. - 31 арк.

7. ДАЛО. Ф. Р-7. Оп. 1. Спр. 40. - 41 арк.

8. ДАЛО. Ф. Р-7. ОП. 1. Спр. 51. -43 арк.

9. ДАЛО. Ф. Р-7. ОП. 1. Спр. 65. - 135 арк.

10. Кошарний I. У сузір'ї соціалістичної культури. Культурне будівництво у возз'єднаних областях 
Української РСР (1939 - 1958 рр.). Львів: Вища школа, $1975.238 \mathrm{c}$.

11. Курносов Ю., Ростикус Р. Розвиток і зміцнення вищої школи в західних областях України в післявоєнний період. Чернівці, 1957.218 с.

12. Лук'яненко О. “Найближчі друзі партії”: колективи педагогічних вишів України в образах щодення 1920-х - першої половини 1960-х років. Полтава: Видавництво “Сімон”, 2019. 658 с.

13. МайбородаВ. Вищапедагогічнаосвітав Україні: історія, досвід, уроки(1917-1985 рр.).Київ: Либідь, 1992. 195 с.

14. Марусик Т., Герегова С. Розвиток вищої освіти в західному регіоні України (друга половина 40-х - перша половина 50-х рр. ХХ ст.). Украӥнський історичний журнал. 1997. №3. С.101-109.

15. Попп Р. Інтелігенція Львова у 1944 - 1953 рр.: етносоціальна характеристика. Наукові зошити історичного факультету Львівського національного університету ім. І. Франка. 2002. Вип. 4. С. 373-383.

16. Рубльов О., Черченко Ю. Сталінщина й доля західноукраїнської інтелігенції, 20-50-ті роки XX ст. Київ: Наук. думка, 1994. 350 с.

17. Свйонтик О., Галів М. Документ з історії повсякденного життя Чернівецького державного учительського інституту (1948р.): археографічний аналіз. Молодь і ринок: щомісячний науковопедагогічний журнал. 2021. № 2(188). С. 16-21.

18. Теоретична плутанина в наукових зошитах. Радянська Украӥна. 1950. 5 квітня.

\section{REFERENCES}

1. Arkhiv Drohobytskoho derzhavnoho pedahohichnoho universytetu imeni Ivana Franka (dali-Arkhiv DDPU). F. 1: LDPI. Spr.: Knyha nakaziv za 1945-1946 n.r. [Archive of Drohobych State Pedagogical University named after Ivan Franko (hereinafter - the Archive of the State Pedagogical University). F. 1: LDPI. File: Book of orders for 1945-1946 academic year.[in Ukrainian].

2. Arkhiv DDPU. F. 1: LDPI. Spr.: Knyha nakaziv 19481949 n.r. [DSPU archive. F. 1: LDPI. Reference: Book of Orders 1948-1949]. [in Ukrainian].

3. Arkhiv DDPU. F. 1:LDPI. Spr.: Knyha nakaziv 19501951 n.r. [DSPU archive. F. 1: LDPI. Reference: Book of Orders 1950-1951]. [in Ukrainian].

4. Arkhiv DDPU. F. 1: LDPI. Spr.: Knyha nakaziv za 1951/52 n.r. [DSPU archive. F. 1: LDPI. Reference: Book of Orders 1951/52]. [in Ukrainian].

5. Arkhiv DDPU. F. 1: LDPI. Spr.: Knyha nakaziv za 1952/53 n.r. [DSPU archive. F. 1: LDPI. Reference: Book of Orders 1952/53]. [in Ukrainian].

6. Derzhavnyi arkhiv Lvivskoi oblasti (dali-DALO). F. R-7: Lvivskyi derzhavnyi pedahohichnyi istytut. Op. 1. Spr. 31. -31 ark. [State Archives of Lviv Region (hereinafter - SALR). FR-7: Lviv State Pedagogical Institute. Op. 1. Ref. 31. -31 sheets]. [in Ukrainian].
7. DALO. F. R-7. Op. 1. Spr. 40. -41 ark. [SALR. F. R-7. Op. 1. Ref. 40. -41 pages]. [in Ukrainian].

8. DALO. F. R-7. Op. 1. Spr. 51. -43 ark. [SALR. F. R-7. Op. 1. Ref. 51. -43 pages]. [in Ukrainian].

9. DALO. F. R-7. Op. 1. Spr. 65. - 135 ark. [SALR. F. R7. Op. 1. Ref. 65. -135 pages]. [in Ukrainian].

10. Kosharnyi, I. (1973). U suziri sotsialistychnoi kultury [In the constellation of socialist culture]. Cultural construction in the reunited regions of the Ukrainian SSR (1939-1958). Lviv, 238 p. [in Ukrainian].

11. Kurnoso, Yu. \& Rostykus, R. (1957). Rozvytok i zmitsnennia vyshchoi shkoly v zakhidnykh oblastiakh Ukrainy $\mathrm{v}$ pisliavoiennyi period [Development and strengthening of higher education in the western regions of Ukraine in the postwar period]. Chernivtsi, $218 \mathrm{p}$. [in Ukrainian].

12. Lukianenko, O. (2019). "Naiblyzhchi druzi partii": kolektyvy pedahohichnykh vyshiv Ukrainy v obrazakh shchodennia 1920-kh - pershoi polovyny 1960-kh rokiv ["The closest friends of the party": groups of pedagogical universities of Ukraine in the images of everyday life of the $1920 \mathrm{~s}$ - first half of the 1960s]. 658 p. [in Ukrainian].

13. Maiboroda, V. (1992). Vyshcha pedahohichna osvita v Ukraini: istoriia, dosvid, uroky (1917-1985 rr.). [Higher pedagogical education in Ukraine: history, experience, lessons (1917-1985)]. Kyiv, 195 p. [in Ukrainian].

14. Marusyk, T. \& Herehova, S. (1997). Rozvytok vyshchoi osvity $\mathrm{v}$ zakhidnomu rehioni Ukrainy (druha polovyna $40-\mathrm{kh}$ - persha polovyna $50-\mathrm{kh}$ rr. XX st.) [Development of higher education in the western region of Ukraine (second half of the 40's - first half of the 50's of the twentieth century)]. Ukrainian Historical Journal. No.3.pp.101-109. [in Ukrainian].

15. Popp, R. (2002). Intelihentsiia Lvova u $1944-1953$ rr: etnosotsialna kharakterystyka [The intelligentsia of Lviv in 1944 - 1953: ethnosocial characteristics]. Scientific notebooks of the historical faculty of Lviv National University named after I. Franko.Vol. 4. pp. 373-383. [in Ukrainian].

16. Rublov, O. \& Cherchenko, Yu. (1994). Stalinshchyna y dolia zakhidnoukrainskoi intelihentsii, 20-50-ti roky XX st. [Stalinism and the fate of the Western Ukrainian intelligentsia, 20-50s of the XX century]. Kyiv, 350 p. [in Ukrainian].

17. Sviontyk, O. \& Haliv, M. (2021). Dokument z istorii povsiakdennoho zhyttia Chernivetskoho derzhavnoho uchytelskoho instytutu (1948 r.): arkheohrafichnyi analiz [Document on the history of everyday life of the Chernivtsi State Teachers' Institute (1948): archeographic analysis]. Youth and the market: a monthly scientific and pedagogical journal. No. 2(188). pp. 16-21. [in Ukrainian].

18. Teoretychna plutanyna $\mathrm{v}$ naukovykh zoshytakh [Theoretical confusion in scientific notebooks]. Soviet Ukraine. 1950. 5 April. [in Ukrainian].

Стаття надійшла до редакції 28.10.2021

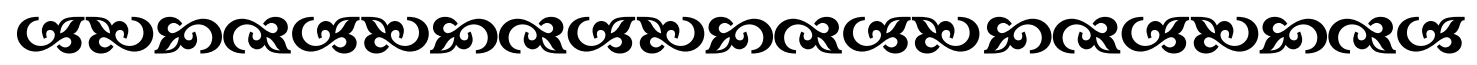

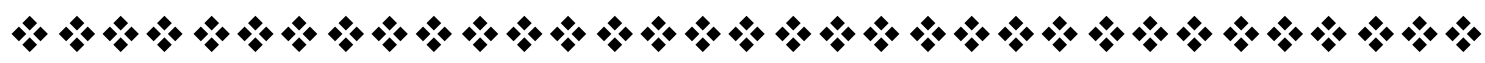

